\title{
RPS6KB1 wt Allele
}

National Cancer Institute

\section{Source}

National Cancer Institute. RPS6KB1 wt Allele. NCI Thesaurus. Code C84315.

Human RPS6KB1 wild-type allele is located in the vicinity of 17q23.1 and is approximately $57 \mathrm{~kb}$ in length. This allele, which encodes ribosomal protein $\mathrm{S} 6$ kinase beta-1 protein, plays a role in the regulation of protein phosphorylation. 